\title{
Performance of microbiological, serological, molecular, and modified seminal plasma methods in the diagnosis of Brucella abortus in semen and serum of bovine bulls ${ }^{\text {is }}$
}

\author{
G. Nardi Júnior ${ }^{\mathrm{a}}$, J. Megid ${ }^{\mathrm{b}}$, L.A. Mathias ${ }^{\mathrm{c}}$, L. Paulin ${ }^{\mathrm{d}}$, A.F. Vicente ${ }^{\mathrm{b}}$, A. Cortez ${ }^{\mathrm{e}}$, \\ F.J.P. Listoni ${ }^{\text {b }}$, G.H.B. Lara ${ }^{\text {b }}$, R.G. Motta ${ }^{\text {b }}$, M.G.M. Chacur ${ }^{\text {f }}$, F.M. Monteiro ${ }^{\mathrm{g}}$, M.G. Ribeiro ${ }^{\text {b. }}{ }^{*}$ \\ a Tecnologia em Agronegócio, Faculdade de Tecnologia de Botucatu (FATEC), SP, Brazil \\ ${ }^{\mathrm{b}}$ Departamento de Higiene Veterinária e Saúde Pública, Faculdade de Medicina Veterinária e Zootecnia, Universidade Estadual Paulista (UNESP), Botucatu, \\ SP, Brazil \\ ${ }^{\mathrm{c}}$ Departamento de Medicina Veterinária Preventiva e Reprodução Animal, Faculdade de Ciências Agrárias e Veterinárias, UNESP, Jaboticabal, SP, Brazil \\ d Laboratório de Doenças Bacterianas da Reprodução do Centro de Pesquisa e Desenvolvimento de Sanidade Animal, Instituto Biológico de São Paulo, SP, \\ Brazil \\ e Doenças Infecciosas dos Animais, Universidade de Santo Amaro, São Paulo, SP, Brazil \\ ${ }^{\mathrm{f}}$ Reprodução Animal, Universidade do Oeste Paulista (UNOESTE), Presidente Prudente, SP, Brazil \\ ${ }^{g}$ Agência Paulista de Tecnologia em Agronegócio (APTA), Bovinos de Corte, Instituto de Zootecnia, Sertãozinho, SP, Brazil
}

\section{A R T I C L E I N F O}

\section{Article history:}

Received 11 July 2016

Received in revised form

7 February 2017

Accepted 19 June 2017

Available online 27 June 2017

\section{Keywords:}

Brucellosis

Males

Seminal plasma

Serodiagnosis

PCR

\begin{abstract}
A B S T R A C T
Brucellosis remains as a major infectious disease of domestic animals and is considered a re-emerging zoonosis in several countries. B. abortus infections in bulls are related to reproductive tract infections, although infected animals show transient serological titers or nonreactor status. Thus, diagnosis of bovine brucellosis based exclusively on serological tests probably underestimates $B$. abortus infections in bulls. In this scenario, three hundred thirty-five serum samples from reproductively mature bovine bulls were subjected simultaneously to standard serodiagnosis using the rose Bengal test (RBT), 2mercaptoethanol (2-ME), complement fixation (CFT), and fluorescence polarization assay (FPA). Furthermore, conventional semen plasma agglutination (SPA) and modified 2-ME, FC and, FPA were carried out in all bulls replaing serum by seminal plasma. Semen from all bulls was also analyzed for sperm viability, microbiological culture in Farrell media, and polymerase chain reaction (PCR). Only eight (2.38\%) semen samples were considered improper for reproduction services (necrospermia and azoospermia), although none of these animals was positive in any of the diagnosis methods used. Five bulls (1.49\%) were simultaneously positive in conventional RBT, 2-ME, SPA, modified 2-ME, microbiological culture in Farrell media, and in PCR for B. abortus strain 19. Two (1.67\%) bulls were positive in PCR for $B$. abortus field strains and negative in all other tests, although semen was considered viable to reproduction service. The identification of $B$. abortus B19 strain in serum and semen of bulls occurred probably due to improper vaccination of males or infection by B19 strain shedding by vaccinated females that could to contaminated environment of farms. In addition, detection of B. abortus field strains only using PCR in bulls without sperm viability abnormalities indicate the need for including molecular methods to improve diagnosis of the disease in bovine bulls.
\end{abstract}

๑) 2017 International Alliance for Biological Standardization. Published by Elsevier Ltd. All rights reserved.

\footnotetext{
क Place where the study was carried out: Department of Veterinary Hygiene and Public Health, UNESP, Botucatu, SP. Brazil.

* Corresponding author. Infectious Diseases of Domestic Animals, School of Veterinary Medicine and Animal Sciences, Department of Veterinary Hygiene and Public Health, Univ. Estadual Paulista (UNESP), Botucatu, SP, Box 560, Code 18618681, Brazil.

E-mail address: mgribeiro@fmvz.unesp.br (M.G. Ribeiro).
}

\section{Introduction}

Brucellosis remains a public health concern and is considered a re-emerging zoonosis in several countries [1]. Brucella infections represent the greatest economic threat to livestock worldwide, particularly in developing countries because of reproductive problems, reduced milk yield, and restrictions to animal movement 
and trade imposed by international regulatory organizations [2].

Brucella abortus is a well-recognized intracellular gram-negative bacteria considered to be the major cause of brucellosis in domestic cattle. In livestock, B. abortus infection is commonly acquired by direct exposure to fluids and tissues from infected fetuses or vaginal discharges after abortion. Alternatively, ingestion of water or pasture contaminated with fetal fluids and tissues, inhalation, sexual contact, and artificial insemination with contaminated semen may be considered in the transmission [3].

In bovine bulls, after intermittent bacteremia, pathogen infects reproductive organs and accessory glands of mature animals [4]. The pathogenicity of $B$. abortus to bovine males is related to seminal vesiculitis, orchitis, and epididymitis [3,5]. Nevertheless, infected bulls could show transient antibody titers or nonreactor status when subjected to conventional serological tests [4]. Thus, diagnosis of bovine brucellosis based exclusively on serological tests probably underestimates $B$. abortus infections in bulls [6].

Despite comprehensive studies involving serodiagnosis of cattle brucellosis [7], minor attention has been reserved to the diagnosis of the disease in bovine bulls using different methods, particularly regarding semen shedding of $B$. abortus [8]. In the current study, 335 serum samples from reproductive mature bovine bulls without apparent signs of reproductive tract inflammation were subjected simultaneously to serodiagnosis using rose Bengal test (RBT), 2mercaptoethanol (2-ME), complement fixation (CFT), and fluorescence polarization assay (FPA). Semen of the same bulls was also analyzed for sperm viability and submitted to microbiological culture in Farrell media, semen plasma agglutination test (SPA), and polymerase chain reaction (PCR). Furthermore, 2-ME, FC and FPA tests were carried out replacing serum by semen of all bulls (modified tests).

\section{Material and methods}

\subsection{Animals and samples}

Serum and semen of 335 bovine bulls used both for natural mating and as semen donors were sampled from 2013 to 2015. These bulls were reproductively mature (older than 36 months) of different breeds or crossbreeds, without any apparent signs of orchitis or inflammation of accessory reproductive glands. Animals came from three states of the central region of Brazil where bovine breeding is common. Semen samples were aseptically collected by electroejaculation. The material was immediately analyzed for sperm viability [9], and classified as viable or non-viable for reproduction services. An aliquot of the semen samples was frozen $\left(-20^{\circ} \mathrm{C}\right)$ for further microbiological culture. Molecular diagnosis of Brucella species was carried out directly from semen, as well as colonies isolated through microbiological culture.

\subsection{Microbiological diagnosis}

All semen samples were subjected to microbiological culture using Farrell media (Oxoid ${ }^{\mathrm{TM}}$ ). Plates were maintained under micro-aerobic conditions $\left(10 \% \mathrm{CO}_{2}\right)$ at $37{ }^{\circ} \mathrm{C}$, and observed every $24 \mathrm{~h}$, for up to 14 days. Colonies suspected of B. abortus were subjected to Gram and Koster's stains. Conventional phenotypic (biochemical) characterization of $B$. abortus was based on $\mathrm{CO}_{2}$ requirements, catalase, oxidase, urease, citrate, urease, thionin, fuchsin, indol, and nitrate reduction tests [10]. In addition, phenotypic differentiation of $B$. abortus field strains and $B$. abortus B19 vaccine strain was carried out by growing the isolates in thionin $(2 \mu \mathrm{g} / \mathrm{mL}$ ), penicillin ( $5 \mathrm{UI} / \mathrm{mL}$ ), and rifampicin $(50 \mu \mathrm{g} / \mathrm{mL})[3,10]$.

\subsection{Serological diagnosis}

Serological diagnosis was performed using RBT, 2ME, CFT, and FPA. RBT, 2-ME, and CFT were performed using previously described antigens and procedures [6,11]. CFT was considered positive when at least $50 \%$ hemolysis occurred at serum dilution $\geq 20$ ICFTU (international complement fixation test units)/mL [11]. The fluorescence polarization assay (FPA), was carried out with the Brucella abortus antibody test kit (Diachemix, USA ${ }^{\mathrm{TM}}$ ), composed of control serum-positive and serum-negative, and 25 times concentrated buffer lipopolysaccharide antigen conjugated fluorescein. Readings were carried out in a polarization analyzer Fluorescent Sentry 100 model (Diachemix, USA ${ }^{\mathrm{TM}}$ ). Results were expressed in milipolarization units (mP). FPA is based on the rotational difference between the soluble antigen molecule (fluorochrome-labeled) and the same molecule attached to the antibody $[12]$. To determine the cutoff point $(\mathrm{CP})$, two-graph-receiver operation technique characteristic (TG-ROC) were used [13].

\subsection{Seminal plasma technique}

All semen samples were submitted to SPA. After treatment with $1 \%$ sodium azide ( $30 \mu \mathrm{L}$ of $1 \%$ sodium azide/mL of semen), the samples were subjected to centrifugation. Seminal plasma was withdrawn and submitted to the conventional SPA [14]. In addition, modified 2-ME, CFT and FPA were performed replacing the same amount of serum by seminal plasma.

\subsection{Molecular diagnosis of semen}

PCR was carried out as described by Richtzenhain et al. [15] based on the 233-bp expected sizes of amplicons for the diagnosis of the genus Brucella direct from semen samples.

Genomic DNA was extracted from semen using enzymatic treatment (proteinase $\mathrm{K}$ ) and boiling. The steps and cycle conditions (40 cycles) for the PCR assay were: initial DNA denaturation at $94{ }^{\circ} \mathrm{C}$ for $5 \mathrm{~min}$, DNA denaturation at $94{ }^{\circ} \mathrm{C}$ for $60 \mathrm{~s}$, primer annealing at $60^{\circ} \mathrm{C}$ for $60 \mathrm{~s}$, DNA extension at $72{ }^{\circ} \mathrm{C}$ for $60 \mathrm{~s}$, and final extension at $72{ }^{\circ} \mathrm{C}$ for $10 \mathrm{~min}$. PCR products were visualized after electrophoresis in $2 \%$ agarose gel stained by ethidium bromide. A molecular weight marker (100-bp ladder Gibco-BRL) was used as size standard. Species of Brucella were detected by PCR according to the description by Lopez-Goñi et al. [16] modified according to Lopez-Goñi et al. [17].

\subsection{Molecular speciation from Brucella colonies}

Genomic DNA was extracted from colonies isolated thought microbiological cultures using boiling procedure. Briefly, $1 \mu \mathrm{L}$ of the DNA sample, $12.5 \mu \mathrm{L}$ of enzyme Kapa 2G Fast Multiplex PCR Kit (Kapa Biosystems ${ }^{\mathrm{TM}}$ ), and 10 pmoles of each primer in a final volume of $25 \mu \mathrm{L}$ were used. The following cycles conditions were used: initial denaturation at $95{ }^{\circ} \mathrm{C}$ for $3 \mathrm{~min}$, followed by template denaturation at $95{ }^{\circ} \mathrm{C}$ for $15 \mathrm{~s}$, primer annealing at $64{ }^{\circ} \mathrm{C}$ for $75 \mathrm{~s}$. Later, a 30-s primer extension at $72{ }^{\circ} \mathrm{C}$ (30 cycles), and final extension phase of $10 \mathrm{~min}$ at $72{ }^{\circ} \mathrm{C}$ were performed. Reactions were carried out in a Multigene (Labnet International, Inc. ${ }^{\mathrm{TM}}$ ) thermocycler. PCR products were analyzed in a $1.5 \%$ agarose gel $[15,17]$.

\section{Results and discussion}

The major results of the current study revealed the occurrence of five bulls (1.49\%) were simultaneously positive in conventional RBT, 2-ME, SPA, modified 2-ME, microbiological culture in Farrell media, and in PCR for B. abortus strain 19. In addition, two (1.67\%) 
bulls were positive in PCR for B. abortus field strains and negative in all other tests, although semen was considered viable to reproduction service; indicating the need for the association of methods in order to improve the diagnosis of brucellosis in bovine bulls.

Vaccination of heifers, periodic serological tests, and elimination of positive animals are the critical tools to control and eradicate bovine brucellosis worldwide [1]. In spite of the recently approved RB51 vaccine in the prevention of bovine brucellosis, the use of B. abortus strain 19 vaccine remains more widespread for bovine heifers in control and eradication programs for the disease worldwide [21]. Five animals sampled in the current study were positive in all conventional serological tests analyzed, and in modified 2ME. The same animals were PCR-positive for B. abortus and showed isolation of $B$. abortus in Farrell media (Table 1). Particularly in Brazil, bovine brucellosis remains an endemic disease in several states and regions [22].

Based on microbiological culture, phenotypic characteristics and PCR analysis, these five isolates were identified as $B$. abortus strain 19. Positive serodiagnosis, SPA, and modified 2-ME in five bovine bulls from Brazil that shedding B. abortus strain 19 in the semen probably was caused by vaccination of male calves or through exposure to a strain 19-related abortion by an adult cow [23,24]. It is important to note that in Brazil, this vaccine is approved exclusively for heifers (3-8 months of age) [24]. In addition, the mechanism of $B$. abortus infection of bovines by B19 vaccine strain shedding in environment by females remains not entirely clear [25]. The presence of mature bulls seropositive for brucellosis in the sampled animals reinforce the recommendation to limit the use B. abortus strain 19 vaccine exclusively to heifers, since higher persistence of serum titers in conventional serological tests have been reported after vaccination of males with strain 19, compared with heifers [6].

Vaccination of bovine bulls with strain 19 may cause orchitis, seminal vesiculitis, and epididymitis, transitorily affecting spermatogenesis [1]. In addition, shedding of B. abortus strain 19 in the semen of bulls several months after vaccination was also described [6]. Five seropositive bulls sampled herein that eliminated B. abortus strain 19 in the semen were considered apt to reproduction services based only on andrologic examination (Table 1). These data highlight the risk of evaluating semen quality in bovine bulls based exclusively on parameters of seminal viability, without subjecting the animals to diagnosis of reproductive diseases, particularly brucellosis [4]. However, semen with Brucella deposited in the vagina does not appear to be high risk for infection, due to local immune response, as opposed to pathogen that is deposited in to the uterus by artificial insemination does frequently lead to infection $[4,6]$.

Semen of only eight animals (2.38\%) were considered nonviable for reproduction services (necrospermia or azoospermia). However, none of these animals showed reactions in serological tests, SPA, or positive results in Farrell culture and PCR (Table 1). Improper viability of semen of these eight animals negative for brucellosis may have been caused by other pathogens, as well as by traumatic, degenerative, and genetic disorders that may affect the quality of the ejaculate of bulls at reproductive age [4,9].

The pathogenic action of $B$. abortus in bulls is intimately associated with seminal vesiculitis, orchitis, and epididymitis [6]. In this context, one bovine bull was followed over 18 months isolating B. abortus from each of 80 ejaculations, with 500 viable organisms/ $\mathrm{mL}$ of semen [18]. Another similar study, isolated B. abortus from 90 of 93 (97.0\%) consecutive semen ejaculations from a bovine bull for five year period. In the same study, the pathogen was recovered from another bovine bull over 2 years and 6 months [19]. Both aforementioned studies detected macroscopic abnormalities in the semen $[18,19]$. Rough $B$. abortus biotype I was identified from the vas deferens and seminal vesicles in a bull, although no isolates were recovered from the semen of this animal on 12 attempts [20]. Nevertheless, despite $B$. abortus targeting the reproductive tract of bovine bulls and the potential elimination of pathogen in the semen, infected males may show transient antibody titers [14] or be nonreactors in conventional serological tests [4-6], difficulting serum diagnosis of brucellosis in bovine bulls.

Modified 2-ME, FCT and FPA were used in all semen samples of 335 bulls by replacing serum with seminal plasma. However, only modified 2-ME agreed with conventional RBT, 2-ME, SPA, PCR, and microbiological culture (Table 1), showing that modified 2-ME may be valuable in the diagnosis of bovine brucellosis in bulls.

Among the 335 semen samples, two (1.67\%) were positive in PCR for field B. abortus isolates, and negative in all the other tests, although semen of these animals was considered viable for reproduction service (Table 1 ). Few studies have detected the DNA of Brucella species in the semen of seronegative bovine bulls [8].

Semen positive in PCR for B. abortus and seronegative in conventional serological tests may be explained by the lower threshold of PCR, which needs fewer microorganisms for positive detection. Overall, detection of $B$. abortus field strains only using PCR in bulls

Table 1

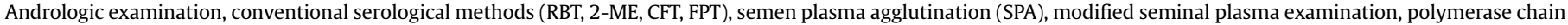
reaction (PCR) and microbiological culture of semen of 335 bulls. Brazil, 2013-2015.

\begin{tabular}{|c|c|c|c|c|c|c|c|c|c|c|c|}
\hline \multirow{2}{*}{$\begin{array}{l}\text { Diagnosis methods } \\
\text { Identification } \\
\text { of bulls }\end{array}$} & \multirow{2}{*}{$\begin{array}{l}\text { Andrologic examination } \\
\text { viability of semen }\end{array}$} & \multicolumn{4}{|c|}{ Serological methods } & \multirow{2}{*}{$\begin{array}{l}\text { Conventional } \\
\text { SPA } \\
\text { SPA }\end{array}$} & \multicolumn{3}{|c|}{ Modified seminal plasma } & \multirow{2}{*}{$\begin{array}{l}\text { Molecular procedures } \\
\text { PCR }\end{array}$} & \multirow{2}{*}{$\begin{array}{l}\text { Microbiological } \\
\text { culture }\end{array}$} \\
\hline & & RBT & 2-ME & FCT & FPA & & 2-ME & $\mathrm{FCT}$ & FPA & & \\
\hline 13 & viable & NR & NR & NR & NR & NR & NR & NR & NR & positive & negative \\
\hline 25 & viable & NR & NR & NR & NR & NR & NR & NR & NR & positive & negative \\
\hline 43 & necrospermia & NR & NR & NR & NR & NR & NR & NR & NR & negative & negative \\
\hline 52 & necrospermia & NR & NR & NR & NR & NR & NR & NR & NR & negative & negative \\
\hline 84 & azoospermia & NR & NR & NR & NR & NR & NR & NR & NR & negative & negative \\
\hline 98 & azoospermia & NR & NR & NR & NR & NR & NR & NR & NR & negative & negative \\
\hline 110 & azoospermia & NR & NR & NR & NR & NR & NR & NR & NR & negative & negative \\
\hline 136 & necrospermia & NR & NR & NR & NR & NR & NR & NR & NR & negative & negative \\
\hline 157 & necrospermia & NR & NR & NR & NR & NR & NR & NR & NR & negative & negative \\
\hline 161 & necrospermia & NR & NR & NR & NR & NR & NR & NR & NR & negative & negative \\
\hline 331 & viable & positive & positive & NR & NR & positive & positive & NR & NR & positive & positive \\
\hline 332 & viable & positive & positive & NR & NR & positive & positive & NR & NR & positive & positive \\
\hline 333 & viable & positive & positive & NR & NR & positive & positive & NR & NR & positive & positive \\
\hline 334 & viable & positive & positive & NR & NR & positive & positive & NR & NR & positive & positive \\
\hline 335 & viable & positive & positive & NR & NR & positive & positive & NR & NR & positive & positive \\
\hline
\end{tabular}

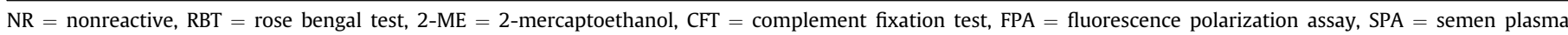
agglutination. 
without sperm viability abnormalities indicate the need for including molecular methods to improve diagnosis of the disease in bovine bulls.

\section{Acknowledgments}

This study was supported by São Paulo Research Foundation (FAPESP), Brazil (Grant 2011/20263-0).

\section{References}

[1] Seleem MN, Boyle SM, Sriranganathan N. Brucellosis: a re-emerging zoonosis Vet Microbiol 2010;140:392-8.

[2] Godfroid J, Nielsen K, Saegerman C. Diagnosis of brucellosis in livestock and wildlife. C Med Journ 2010;51:296-305.

[3] Quinn PJ, Markey BK, Leonard FC, Fitzpatrick FC, Fanning S, Hartigan PJ. Veterinary microbiology and microbial disease. UK: Wiley-Blackwell; 2011. p. 334-41.

[4] Constable PD, Hinchcliff KW, Done S, Gruenberg W. Veterinary medicine: a textbook of the diseases of cattle, horses, sheep, pigs, and goats. 11.ed. W.B. Saunders, Philadelphia, 2278pp.

[5] Songer JG, Post KW. Bacterial and fungal agents of animal disease. Veterinary microbiology. St Louis: Elsevier Saunders; 2005, p. 84-91.

[6] Nielsen K, Duncan JR. Animal brucellosis. Boca Raton: CRC Press; 1990. 453pp.

[7] Gall D, Nielsen K. Serological diagnosis of bovine brucellosis: a review of test performance and coast comparison. Revue scientifique et technique. Office International des Épizooties 2004;23:989-1002.

[8] Junqueira Júnior DG, Rosinha GM, Carvalho CEG, Oliveira CE, Sanches CC Lima-Ribeiro AMC. Detection of Brucella spp. DNA in the semen of seronegative bulls by polymerase chain reaction. Trans Emer Diseas 2012;60(4): 376-7.

[9] Palmer CW. Welfare aspects of theriogenology: investigating alternatives to eletroejaculation of bulls. Theriog 2005;64:469-79.

[10] Alton GG, Jones LM, Angus RD, Verger JM. Techniques for the brucellosis laboratory. Paris: INRA; 1988.

[11] Office International Des Epizooties-OIE. Bovine brucellosis. In: Manual of diagnosis test and vaccines for terrestrial animals; 2010. 35pp.
[12] Nielsen K, Gall D. Fluorescence polarization assay for the diagnosis of brucellosis: a review. J Imm Immuno 2001;22:183-201.

[13] Greiner M, Sohr D, Göbel P. A modified ROC analysis for the selection of cut-off values and the definition of intermediate results of serodiagnostic tests. J Im Meth 1995; $185: 123-32$

[14] Casas Olascoaga R. Diagnóstico serológico de la brucelosis, 18th. World Health Organization; 1976. p. 107-41.

[15] Richtzenhain LJ, Cortez A, Heinemann MB, Soares RM, Sakamoto SM, Vasconcellos SA, et al. Multiplex PCR for detection of Brucella spp. and Leptospira spp. DNA from aborted bovine fetuses. Vet Microbiol 2002;87:139-47.

[16] López-Goñi I, García-Yoldi D, Marín CM, De Miguel MJ, Muñoz PM, Blasco JM, et al. Evaluation of a Multiplex PCR assay (Bruce-ladder) for molecular typing of all Brucella species, including the vaccine strains. J Clin Microbiol 2008;46(10):3484-7.

[17] López-Goñi I, García-Yoldi D, Marín CM, De Miguel MJ, Barquero-Calvo E, Guzmán-Verri C, et al. New Bruce-ladder multiplex PCR assay for the biovar typing of Brucella suis and the discrimination of Brucella suis and Brucella canis. Vet Microbiol 2011;154:152-5.

[18] Manthei CA, DeTray DE, Goode Jr ER. Brucella infection in bulls and the spread of brucellosis in cattle by artificial insemination. I. Intrauterine injection. Proc Am Vet Med Ass 1950;87:177-84.

[19] Plant JW, Claxton PD, Jakovljevic D, DeSaram W. Brucella abortus infection in the bull. Aust Vet Journ 1976;52(1):17-20.

[20] Lambert G, Manthei CA, Deyoe BL. Studies on Brucella abortus infection in bulls. Am Journ Vet Res 1963;24(103):1152-6.

[21] Olsen S, TatumF. Bovine brucellosis. Veterinary Clin N. Am Food Animal Pract 2010;26:15-27.

[22] Poester FP, Gonçalves VSP, Lage AP. Brucellosis in Brazil. Vet Microb 2002;90: 55-62.

[23] Brasil, Ministério da Agricultura, Pecuária e Abastecimento. Brasilia, Distrito Federal: Departamento de Defesa Animal, Manual técnico do Programa Nacional de Controle e Erradicação da Brucelose e Tuberculose Bovina PNCEBT; 2009. 184pp.

[24] Jardim GC, Pires PP, Mathias LA, Ribeiro OC, Kuchembuck MRG. Diagnóstico sorológico da brucelose bovina em animais adultos vacinados com dose reduzida da cepa 19 de Brucella abortus. Pesq Vet Bras 2006;26(3):177-82.

[25] Pacheco WA, Genovez ME, Pozzi CR, Silva LMP, Azevedo SS, Did CC, et al Excretion of Brucella abortus vaccine B19 strain during a reprodutive cycle in dairy cows. Braz J Microbiol 2012;43:594-601. 